\title{
Expression of Functional Mouse Muscle Acetylcholine Receptors in Chinese Hamster Ovary Cells
}

\author{
John R. Forsayeth, ${ }^{1}$ Alfredo Franco, Jr., ${ }^{2}$ Alexander B. Rossi, ${ }^{1}$ Jeffry B. Lansman, ${ }^{2}$ and Zach W. Hall ${ }^{1}$ \\ Departments of ${ }^{1}$ Physiology and ${ }^{2}$ Pharmacology, School of Medicine, University of California, San Francisco, California \\ 94143-0444
}

CHO cells were transfected with cDNAs for all 4 subunits of the mouse muscle acetylcholine receptor (AChR) to obtain a stable cell line (CHO-AR) expressing the AChR on its surface. Immunoprecipitation experiments established that the AChR contained $\alpha$ - and $\beta$-subunits assembled with $\gamma$ - and/ or $\delta$-subunits. In addition, one of the toxin-binding sites of the AChR was blocked by a myasthenic serum that specifically recognizes AChR containing the $\gamma$-subunit. AChR from the CHO-AR cells had the same sedimentation rate, association rate constant for the binding of $\alpha$-bungarotoxin ( $\alpha \mathrm{BTX}$ ), and the same metabolic half-life as the AChR in myotubes of the mouse muscle cell Ine C2C12. Electrophysiological assay of CHO-AR cells by single-channel recording showed the presence of ACh-responsive ion channels with the characteristics of the embryonic AChR ( $\gamma=40 \mathrm{pS}, \tau=5.6 \mathrm{msec}$ ). In some patches a smaller conductance channel was also seen that may represent partially assembled receptor. Fluorescence microscopy of fixed, permeabilized cells stained with rhodamine- $\alpha$-BTX demonstrated both perinuclear and diffuse surface staining. The expression of fully assembled, functional mammalian muscle AChR in nonmuscle cells will allow detailed investigation of its properties and interactions with other cellular components.

The nicotinic acetylcholine receptor $(\mathrm{AChR})$ is a cation-specific ion channel whose opening and closing is regulated by the neurotransmitter, ACh. The oligomeric receptor is composed of 4 different subunits in the molar ratio $\alpha_{2} \beta \gamma \delta$ that are held together by hydrophobic interactions (Changeux et al., 1984). In mammalian muscle, the receptor forms densely packed arrays at the crests of the folds of the postsynaptic membrane (Salpeter, 1987). During development of the neuromuscular junction, the amount of receptor, its subunit composition, and its distribution on the muscle surface change (Schuetze and Role, 1987). Although the structure and functional properties of the AChR are now known in great detail, very little is understood of the mechanisms of

\footnotetext{
Received Feb. 12, 1990; revised Apr. 9, 1990; accepted $\Lambda$ pr. 12, 1990.

We thank Drs. Jon Lindstrom and Stanley Froehner for generously providing monoclonal antibodies; Drs. John Merlie and Norman Davidson for AChR cDNAs; Drs. Peter Gunning and Lawrence Kedes for the expression vector; Dr. Yong Gu for suggesting the assay for internal receptor, as well as for continuous help and advice; Dr. Richard Myers for assistance with DNA subcloning; David Printz for help with the Southern blot; Raymond Chavez for the plasmid drawing and the other members of the Hall laboratory for their encouragement and comments on the manuscript. This work was supported by grants from the National Institutes of Health and the Muscular Dystrophy Association.

Correspondence should be addressed to Dr. John Forsayeth at the above address. Copyright (C) 1990 Society for Neuroscience $0270-6474 / 90 / 082771-09 \$ 03.00 / 0$
}

receptor assembly or of the molecular interactions that control its distribution in the surface membrane.

The recent availability of cDNA clones for the AChR from Torpedo electric organ and from mammalian muscle has made it possible to express the AChR in nonmuscle cells. Fully functional Torpedo and mammalian receptors are formed in Xenopus oocytes, for example, after the injection of an appropriate mixture of receptor subunit mRNAs synthesized in vitro from cDNA (Mishina et al., 1984, 1986). In combination with in vitro mutagenesis, this expression system has been a powerful tool for the investigation of AChR channel function (Miller, 1989).

Stable expression of the complete AChR in mammalian cells could allow similar studies of the synthesis and assembly of the receptor and its interaction with other cellular components. Claudio et al. (1987, 1989) have obtained functional AChR in fibroblasts after introduction of genes encoding Torpedo receptor subunits. A disadvantage of using AChR from Torpedo electric organ, however, is that many of the properties of the protein cannot easily be studied in its native environment so that comparison of its behavior in normal and transfected cells is difficult. In contrast, the physiological and biochemical properties of mammalian muscle receptor have been studied extensively both in intact muscle fibers and in cultures of primary muscle cells or muscle cell lines (Schuetze and Role, 1987). Expression of mammalian $\mathrm{AChR}$ in a nonmuscle cell would allow comparison of its properties to those of the endogenous muscle receptor in the absence of interaction with other muscle proteins. Expression of individual muscle AChR subunits or combinations of them have already been useful in the investigation of the ligandbinding sites of the AChR (Blount and Merlie, 1988, 1989). We report here the transfection of Chinese hamster ovary (CHO) cells with cDNAs encoding all 4 subunits of the embryonic $\mathrm{AChR}$ and describe the properties of the functional AChR expressed in these cells.

\section{Materials and Methods}

Expression vectors. cDN $\Lambda$ s coding for the 4 subunits of the mouse nicotinic AChR, were obtained from Drs. J. Merlie and N. Davidson ( $\alpha$, Isenberg et al., 1986; $\beta$, Buonanno et al., 1986; $\gamma$, Yu et al., 1986; $\delta$, LaPolla et al., 1984). Each cDNA was cloned into a mammalian expression vector (Fig. 1) obtained from Dr. P. Gunning and Dr. L. Kedes (Gunning et al., 1987). The salient features of this plasmid are (1) the human $\beta$-actin promoter, (2) the $5^{\prime}$-untranslated region and first intron of the $\beta$-actin gene, and (3) a neomycin-resistance gene under control of the SV2 promoter.

Cell culture. CHO-DUKX-B1 cells (Urlaub and Chasin, 1980), deficient in the enzyme dihydrofolate reductase (EC 1.5.1.3), were obtained from the Tissue Culture Facility at UCSF and were maintained in Ham's F-12 medium with $10 \%$ fetal calf serum. C2C12 myoblasts were grown in DME-H16 with $20 \%$ fetal calf serum and $0.5 \%$ chick embryo extract 


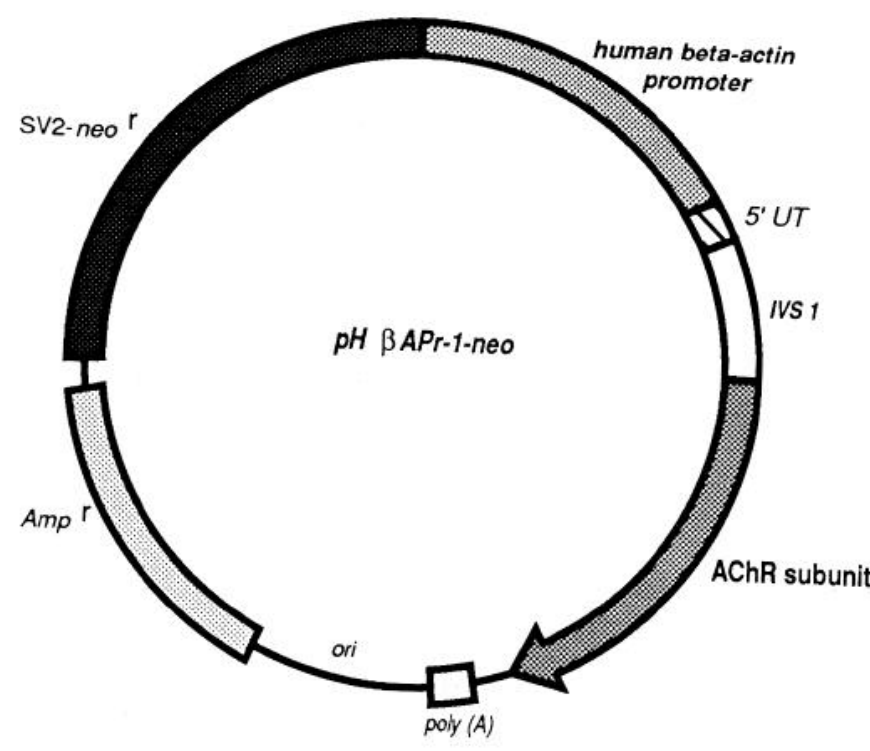

Figure 1. Restriction map of expression vector used for transfection. The vector is further described in Materials and Methods and in Gunning et al. (1987).

(Gibco, CA) and were induced to differentiate by serum deprivation as described previously (Inestrosa et al., 1983; Ralston and Hall, 1989).

Transfection of $\mathrm{CHO}$ cells. Transfection of $\mathrm{CHO}$ cells was performed by the calcium phosphate method (Wigler et al., 1979). Briefly, $10 \mu \mathrm{g}$ of each plasmid DNA was added to $250 \mathrm{mM} \mathrm{CaCl}$; this was mixed with an equal volume of HEPES-buffered saline and a fine precipitate allowed to form. The DNA-calcium phosphate precipitate was then added to $10^{6} \mathrm{CHO}$ cells in a $10 \mathrm{~cm}$ dish and incubated at room temperature for $30 \mathrm{~min}$. After the addition of $15 \mathrm{ml}$ medium, the cells were incubated for $4 \mathrm{hr}$ at $37^{\circ} \mathrm{C}$ and the medium replaced for $5 \mathrm{~min}$ with medium containing glycerol $(20 \% \mathrm{vol} / \mathrm{vol})$. The cells were then selected in medium containing $0.4 \mathrm{mg} / \mathrm{ml} \mathrm{G} 418$ (Gibco, CA). The cells were maintained in selective medium for 7-10 d. Individual clones were isolated by means of cloning cylinders and subcloned by limiting dilution in a 96-well plate.

Analysis of RNA. Cytoplasmic RNA was extracted by the method of Favaloro et al. (1980). The RNA was quantitated spectrophotometrically and stored at $-70^{\circ} \mathrm{C}$ under $70 \%$ ethanol. Twenty micrograms of each RNA were separated on a $1 \%$ formaldehyde-agarose gel and transferred to a Nylon membrane by capillary action (Fourney et al., 1988). The membrane was prehybridized in $6 \times \mathrm{SSC}, 50 \%$ formamide, 0.1 $\mathrm{mg} / \mathrm{ml}$ denatured salmon sperm DNA, $1 \times$ Denhardt's solution, $0.1 \%$ SDS, and $10 \%$ dextran sulfate at $42^{\circ} \mathrm{C}$ for $2 \mathrm{hr}$ and, after addition of the appropriate random primer-generated $\left[\alpha{ }^{32} \mathrm{P}\right]$-dCTP-labeled cDNA probe $\left(1 \times 10^{6} \mathrm{cpm} / \mathrm{ml}\right)$ to this solution, hybridized for $14-16 \mathrm{hr}$ at $42^{\circ} \mathrm{C}$. The membranes were then washed twice at $25^{\circ} \mathrm{C}$ in $2 \times \mathrm{SSC}$, $0.1 \% \mathrm{SDS}$, and once at $55^{\circ} \mathrm{C}$ in $0.2 \times \mathrm{SSC}, 0.1 \% \mathrm{SDS}$. In experiments in which synthetically transcribed subunit mRNAs were probed with the cDNAs for the 3 other subunits the signals were about 100 -fold lower under the above hybridization conditions (data not shown). The membranes were then exposed to an X-ray film with an intensifying screen at $-70^{\circ} \mathrm{C}$.

Immunoblots. Confluent cells were washed 3 times with ice-cold PBS, taken up in the last wash and pelleted by centrifugation. The pellet was solubilized in $0.2 \mathrm{ml} 50 \mathrm{~mm}$ Tris- $\mathrm{HCl}$ (pH 7.4) buffer, containing $1 \%$ Triton X-100, $50 \mathrm{~mm} \mathrm{NaCl}$ and protease inhibitors (Brockes and Hall, 1975). The extract was centrifuged to remove insoluble material and incubated with the appropriate antibodies to precipitate AChR subunits. Monoclonal antibodies 61 and 124 (Tzartos et al., 1981; Gullick and Lindstrom, 1983) were used for the $\alpha$ - and $\beta$-subunits, respectively, and $\mathrm{mAb} 88 \mathrm{~B}$ was used for the $\gamma$ - and $\delta$-subunits (Froehner et al., 1983; Gu and Hall, 1988). In addition, subunit-specific antisera were used for $\gamma$ and $\delta$-subunit detection (Gu and Hall, 1988). The immunoprecipitates were subjected to SDS-PAGE and immunoblotting as described (Gu and Hall, 1988).

${ }^{125} I$ - $\alpha$-bungarotoxin $\left({ }^{125} I-\alpha B T X\right)$ binding assays. Two types of assays
Table 1. ${ }^{125 I}-\alpha$-bungarotoxin binding to the surface of CHO-AR subclones and $\mathrm{C} 2$ myotubes

Culture

Binding ( $\mathrm{fmol} / \mathrm{mg}$ protein)

C2 myotubes

CHO-AR9

$464.8 \pm 10.2(100)$

CHO-AR42

$50.0 \pm 2.80(10)$

$52.4 \pm 3.3(11)$

$\mathrm{C} 2$ myotubes or $\mathrm{CHO}$ cells, cultured in multiwells, were incubated for $90 \mathrm{~min}$ at $37^{\circ} \mathrm{C}$ in culture medium containing $10 \mathrm{nM}{ }^{125} \mathrm{I}-\alpha \mathrm{BTX}$. Unlabeled $\alpha \mathrm{BTX}(1 \mu \mathrm{M})$ was included in some wells to determine nonspecific binding. Values are the mean \pm SEM of 3 determinations. Numbers in parentheses represent toxin binding as a percentage of the value obtained in $\mathrm{C} 2$ myotubes.

were performed to quantitate $\mathrm{AChRs}$ in both $\mathrm{C} 2$ and $\mathrm{CHO}-\mathrm{AR}$ cells. First, surface AChR was determined by incubation of cells in culture medium containing $10 \mathrm{nM}{ }^{125} \mathrm{I}-\alpha \mathrm{BTX}$ for $90 \mathrm{~min}$ at $37^{\circ} \mathrm{C}$. Nonspecific binding was determined by the inclusion of $1 \mu \mathrm{M}$ unlabeled $\alpha$ BTX. To determine total and surface receptor on aliquots of the same cells, the cells were incubated in the presence of ${ }^{125} \mathrm{I}-\alpha \mathrm{BTX}$ as described above. After washing the cells 3 times in PBS, they were dislodged, pelleted by centrifugation, and counted in a gamma counter to determine surface AChR. The pellets were then solubilized in $1 \%$ Triton X-100 (Brockes and Hall, 1975), and various amounts of the soluble fraction were mixed with a further aliquot of ${ }^{125} \mathrm{I}-\alpha \mathrm{BTX}$ to a final concentration of $50 \mathrm{~nm}$ and $50 \mu$ l of packed mAb 88B-Sepharose beads. Parallel incubations were performed without the addition of ${ }^{125} \mathrm{I}-\alpha \mathrm{BTX}$ in order to calculate the efficiency of the immunoprecipitation and the linearity of the assay. Next, the mixtures were agitated for $2 \mathrm{hr}$ at $4^{\circ} \mathrm{C}$, and the binding was terminated by washing the beads 3 times in Triton buffer supplemented with $1 \mathrm{M} \mathrm{NaCl}$. The beads were then counted in a gamma counter. After correcting for the efficiency of the immunoprecipitation, these values give a measure of total and surface receptor. The difference between the 2 equals the amount of internal receptor. Another measure of internal receptor was obtained by a similar assay except that the intact cells were incubated with $10 \mathrm{~nm}$ unlabeled $\alpha$ BTX. The results obtained by the 2 methods were the same, and the assay was linear with respect to receptor quantity over a wide range (not shown).

Other procedures. Velocity sedimentation of labeled $\mathrm{AChR}$ was performed with a $5-20 \%$ sucrose gradient as previously described (Black et al., 1987). CHO-AR and C2 myotubes were fixed, permeabilized, and stained with rhodamine-conjugated $\alpha \mathrm{BTX}$ as previously described (Gu et al., 1989). Protein was assayed by the method of Bradford (1976); BSA was used as a standard.

Electrophysiological methods. The activity of single ACh receptor channels was recorded from cell-attached and from outside-out patches on the surface of CHO-AR cells as described by Hamill et al. (1981). Patch pipets were pulled in 2 steps from Boralex hematocrit pipet (Rochester Scientific) coated with Sylgard (Dow Corning), and fire-polished with a microforge. Pipets had resistances of 4-6 M $\Omega$ with standard saline in the pipet and isotonic potassium-aspartate in the bath. Current signals were recorded with a List EPC-7 patch-clamp amplifier. Current signals recorded at a constant holding potential were stored on video tape. All recordings were done at room temperature $\left(21-25^{\circ} \mathrm{C}\right)$. Standard saline contained $150 \mathrm{~mm} \mathrm{NaCl}, 5 \mathrm{~mm} \mathrm{KCl}, 1 \mathrm{~mm} \mathrm{MgCl}_{2}, 2.5 \mathrm{~mm} \mathrm{CaCl}_{2}, 10$ $\mathrm{mm}$ HEPES, and $17 \mathrm{~mm}$ glucose. The $\mathrm{pH}$ was adjusted to 7.5 with tetraethylamonium hydroxide and the osmolarity to 320-330 mOsm with glucose. Acetylcholine chloride, carbamylcholine chloride, and curare (Sigma) were stored at $0^{\circ} \mathrm{C}$ as $1 \mathrm{~mm}$ stock solutions in normal saline. The bathing solution was an isotonic potassium solution ( $\mathrm{K}$-aspartate) containing $5 \mathrm{~mm} \mathrm{MgCl}_{2}, 10 \mathrm{~mm} \mathrm{~K}-E G T A$, and $10 \mathrm{~mm}$ HEPES. The $\mathrm{K}$-aspartate bathing solution was used to zero the resting potential of the cell such that the patch potential was identical to the applied voltage command. This was verified by the single-channel current-voltage relationship measured after patch excision, which was not measurably different from that obtained prior to excising the patch. The K-aspartate bathing solution produced no detectable signs of cell deterioration.

Current records were stored on video tape and replayed onto the hard disk of a PDP 11/73 laboratory computer (Indec Systems, Sunnyvale, CA) for analysis after filtering with an 8-pole Bessel filter $(-3 \mathrm{~dB})$. For the analysis of channel kinetics, current records were filtered at $2 \mathrm{kHz}$ and digitized at $10 \mathrm{kHz}$. For the plotting of current records, the data were either filtered at 0.5 or $1 \mathrm{kHz}$ and digitized at 2.5 or $5 \mathrm{kHz}$, 


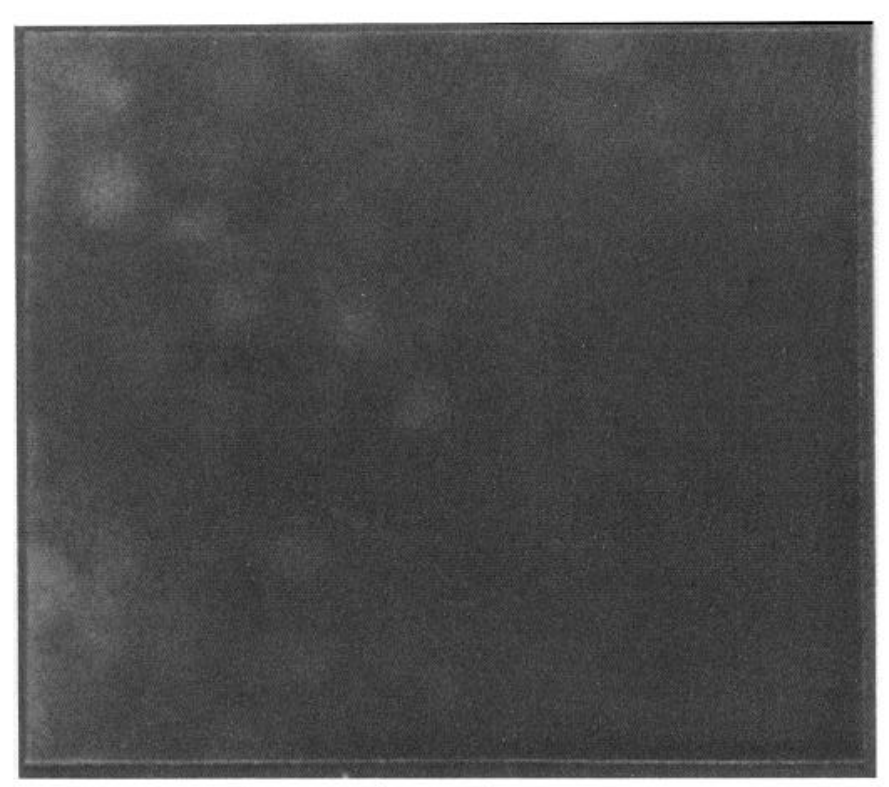

$\mathrm{CHO}$

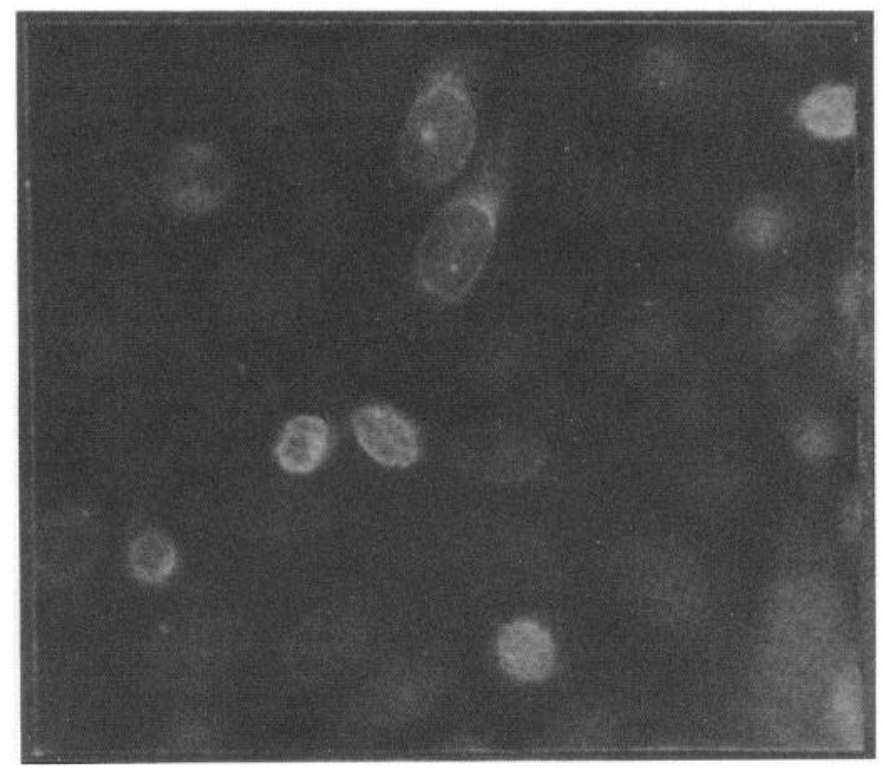

\section{CHO-AR 9}

Figure 2. Staining of $\mathrm{C} 2$ and $\mathrm{CHO}$ cells with rhodamine- $\alpha-\mathrm{BTX}$. $\mathrm{C} 2$ myotubes, untransfected $\mathrm{CHO}$ or transfected $\mathrm{CHO}$ cells (CHO-AR9 and CHO-AR42) were grown on glass coverslips, fixed with paraformaldehyde, permeabilized with saponin, and stained with rhodamine- $\alpha$-BTX as described in Materials and Methods. Representative areas of each slide were photographed on a fluorescence microscope.

respectively. The open channel level was manually set with cursors on the computer display. Channel open and closed times were determined with a threshold set at half the amplitude of the unitary current (Colquhoun and Sigworth, 1983). From the idealized reconstruction of open and closed intervals, histograms of open times were constructed. A maximum likelihood fitting routine was used to fit open time histograms as a sum of exponentials of the form

$$
f(t)=\sum a_{i}\left(\frac{1}{t_{i}}\right) \exp \left(-\frac{t}{t_{i}}\right),
$$

where $a_{i}$ represents the area of the $i$ th component $\left(\Sigma a_{i}=1\right)$ and $t_{i}$ its time constant (Colquhoun and Sigworth, 1983). Events that were twice the sampling interval were excluded from the histograms, and a correction for missed events was made during the fitting procedure.

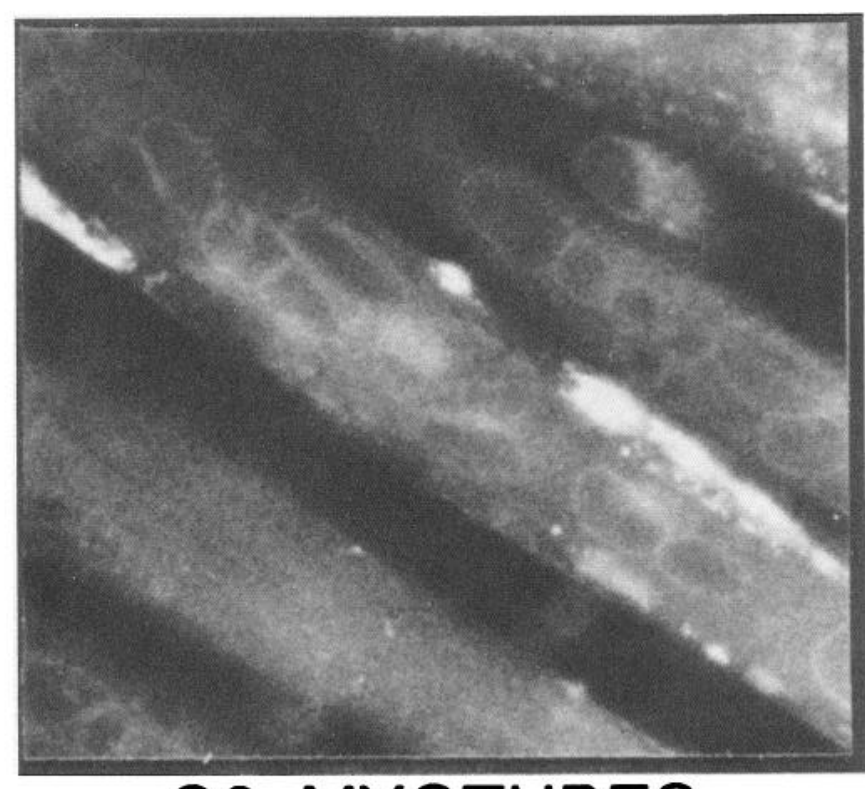

C2 MYOTUBES

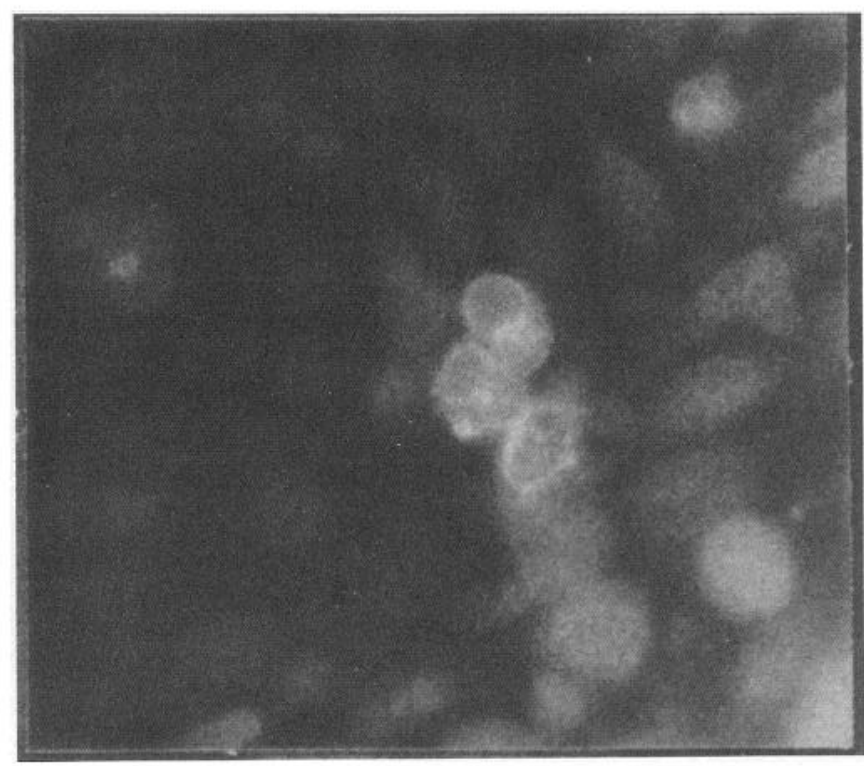

CHO-AR 42

\section{Results}

CHO cells were transfected with a mixture of 4 mouse AChR subunit cDNAs contained in separate copies of an expression vector that confers neomycin resistance on mammalian cells. After growth in selective medium, 48 clones were isolated and screened for the expression of ${ }^{125} \mathrm{I}-\alpha \mathrm{BTX}$ binding on the cell surface. Two of the clones (AR9 and AR42) bound $\alpha$ BTX at about $10 \%$ of the level observed with $\mathrm{C} 2 \mathrm{C} 12$ myotubes (Table 1). Clone AR42 was subcloned twice to give a line designated $\mathrm{CHO}-\mathrm{AR}$ that was used for all subsequent experiments.

Binding of $\alpha$ BTX to individual cells was visualized in fixed, 

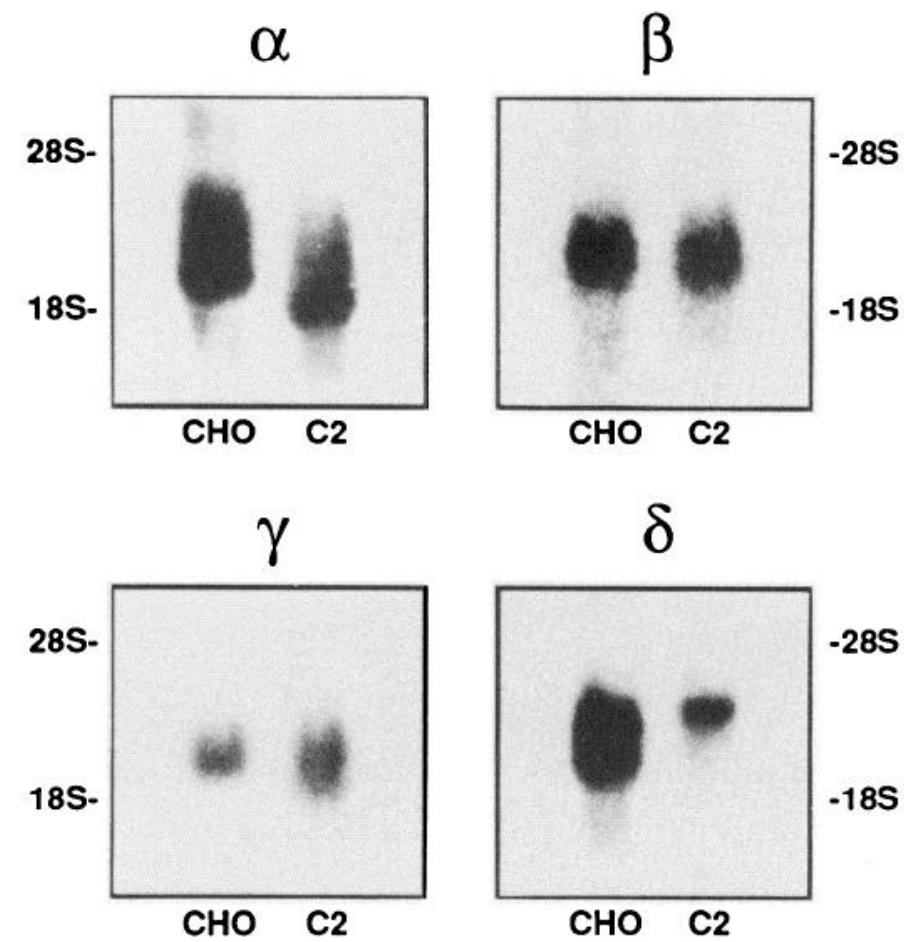

Figure 3. Northern blot of RNA from C2 myotubes and CHO-AR cells. RNA samples $(20 \mu \mathrm{g})$ were separated on $1 \%$ agarose-formaldehyde gels, transferred to Nylon membranes, and hybridized to cDNAs coding for the $\alpha-, \beta$-, $\gamma$-, or $\delta$-subunits of the mouse ACh receptor, respectively. The washed membranes were then exposed to X-ray film for 14-16 hr at $-70^{\circ} \mathrm{C}$ in the presence of an intensifying screen. The positions of the ribosomal bands were determined by ethidium bromide staining.

permeabilized cells by fluorescence of rhodamine-conjugated $\alpha$ BTX. Staining was seen in only about $10 \%$ of the cells in the case of each clone. Repeated subcloning failed to increase the fraction of cells with detectable binding of rhodamine-conjugated $\alpha \mathrm{BTX}$. The cells that bound toxin showed both intracellular perinuclear staining and diffuse surface staining (Fig. 2). Dense patches of $\mathrm{AChR}$, such as those seen in $\mathrm{C} 2$ myotubes, were not seen.

\section{AChR subunits}

Several types of experiments were performed to determine whether the toxin-binding activity found in the transfected cells represented $\mathrm{AChR}$ containing all 4 subunits. We first used Northern blot analysis to test for expression of each of the 4 mRNAs. After electrophoresis and transfer to a Nylon membrane, total RNA, prepared from $\mathrm{C} 2$ myotubes or from CHO-AR cells, was hybridized with ${ }^{32} \mathrm{P}$-labeled cDNA fragments coding for the mouse $\alpha-, \beta-, \gamma-$, and $\delta$-subunits (Fig. 3). For each of the subunits a single major band was seen with $\mathrm{CHO}-\mathrm{AR}$ mRNA that was approximately the same size as that seen with $\mathrm{C} 2$ mRNA. When equal amounts of total RNA were compared, the intensities of the bands from $\mathrm{CHO}-\mathrm{AR}$ cells were 1-2 times as intense as the same bands from C2 RNA. In shorter exposures of the autoradiogram shown in Figure 3, the $\delta$ band in the CHO-AR RNA appeared as a doublet, probably reflecting the presence of more than one polyadenylation signal.

To detect individual subunits of the AChR, CHO-AR cells were extracted with detergent and the extract immunoprecipitated with monoclonal antibody $\mathrm{mAb} 88 \mathrm{~B}$ (Froehner et al.,

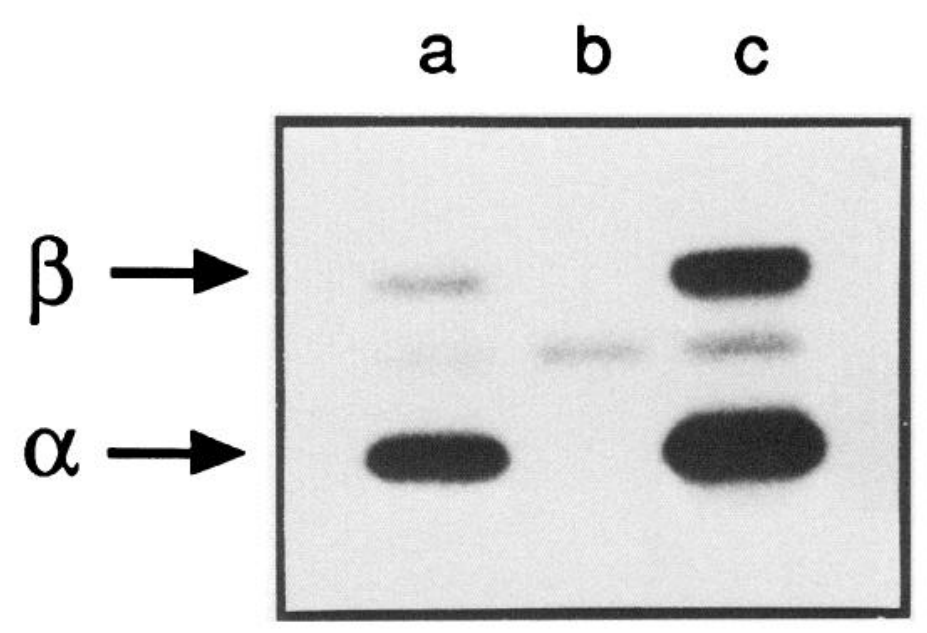

Figure 4. Western blot of immunoprecipitates from $\mathrm{C} 2$ myotubes, $\mathrm{CHO} \alpha 7$, and CHO-AR cells. CHO-AR cells $(a), \mathrm{CHO} \alpha 7$ cells $(b)$, or $\mathrm{C} 2$ myotubes $(c)$ were extracted in $1 \%$ Triton and the extracts immunoprecipitated with mAb 88B coupled to Sepharose. The immunoprecipitates were then separated on SDS-PAGE, transferred to nitrocellulose. The membranes were incubated first with mAbs 61 and 124, which recognize the $\alpha$-and $\beta$-subunits of the AChR, respectively, second with rabbit anti-rat IgG, and third with ${ }^{125}$ I-donkey anti-rabbit IgG. After the membranes were washed, they were exposed to X-ray film at $-70^{\circ} \mathrm{C}$ for $1-2 \mathrm{~d}$.

1983), which recognizes predominantly the $\delta$ - and, to a lesser extent, the $\gamma$-subunit of the muscle AChR (Gu and Hall, 1988). Parallel immunoprecipitations were performed on extracts of $\mathrm{C} 2$ myotubes and of transfected $\mathrm{CHO}$ cells $(\mathrm{CHO} \alpha 7)$, which express only the $\alpha$-subunit of the AChR (Forsayeth and Hall, unpublished observations). Each of the immunoprecipitates was separated on SDS-PAGE, transferred to nitrocellulose and immunoblotted with antibodies to each of the 4 subunits. MAbs 61 and 124 were used to detect the $\alpha$ - and $\beta$-subunits, respectively (Tzartos et al., 1981; Gullick and Lindstrom, 1983); mAb 88 and subunit-specific antisera were used to test for the $\gamma$ - and $\delta$-subunits (Gu and Hall, 1988). As shown in Figure 4, $\alpha$ - and $\beta$-subunits were detected in the immunoprecipitates from both $\mathrm{C} 2$ myotubes and $\mathrm{CHO}-\mathrm{AR}$ cells, but not in that from $\mathrm{CHO} \alpha 7$ cells. Because the extracts were immunoprecipitated with an antibody to the $\delta / \gamma$-subunits, both $\alpha$ - and $\beta$-subunits in CHOAR42 cells must thus be associated with the $\delta$ - and/or the $\gamma$-subunits. Densitometric scanning of the $\alpha$ - and $\beta$-subunit bands confirmed that the ratio of $\alpha$ to $\beta$ was the same in $\mathrm{C} 2$ and $\mathrm{CHO}-$ AR blots. Attempts to detect $\gamma$ - and $\delta$-subunits directly with either mAb $88 \mathrm{~B}$ or antisera specific for the $\gamma$ - or $\delta$-subunits $(\mathrm{Gu}$ and Hall, 1988) were unsuccessful. Because of their susceptibility to proteolysis (Gullick and Lindstrom, 1983), the $\gamma$ - and $\delta$-subunits have also been difficult to detect in muscle cells (Merlie and Sebbane, 1981; Gu and Hall, 1988).

Indirect evidence indicated that the $\gamma$-subunit was part of the assembled AChR. A myasthenic serum that specifically blocks toxin binding to 1 of the 2 sites of the mouse muscle AChR (Gu et al., 1985) has recently been shown to bind only to AChR containing $\gamma$-subunit (Gu and Hall, unpublished observation). The antiserum presumably blocks toxin binding to the $\alpha$-subunit that neighbors $\gamma$ (Blount and Merlie, 1989). After CHO-AR cells were preincubated with this serum, binding of ${ }^{125} \mathrm{I}-\alpha \mathrm{BTX}$ was reduced by $44 \%$; the comparable figure for $\mathrm{C} 2$ cells was $40 \%$ (Table 2). In contrast, nonimmune serum had only a slight effect on toxin binding in both cell lines. We conclude that the 


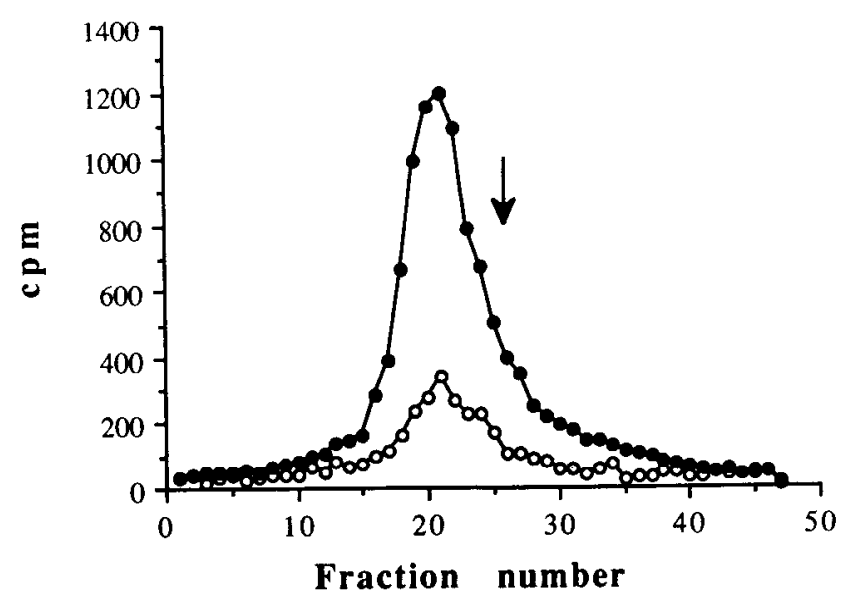

Figure 5. Velocity sedimentation of $\mathrm{AChR}$ from $\mathrm{C} 2$ myotubes and CHO-AR cells. Dishes of C2 myotubes (filled circles) or CHO-AR cells (open circles) were incubated with $10 \mathrm{nM}^{125} \mathrm{I}-\alpha \mathrm{BTX}$ for $90 \mathrm{~min}$ at $37^{\circ} \mathrm{C}$, washed 3 timcs with PBS, and then solubilized in $1 \%$ Triton X-100. After centrifugation, the extracts were applied to a 5-20\% sucrose gradient and centrifuged at $130,000 \times g$ for $14 \mathrm{hr}$. Fractions of $100 \mu \mathrm{l} \mathrm{each}$ were taken from the bottom of the gradient and counted in a gamma counter. The arrow indicates the location of a $6.3 \mathrm{~S}$ size marker (alkaline phosphatase).

AChR expressed on the surface of CHO-AR cells contains the $\gamma$-subunit.

\section{Biochemical properties of the $A C h R$}

The toxin-binding activity expressed on the surface of CHOAR cells was further characterized by sucrose density sedimentation. Receptors on the surface of $\mathrm{C} 2$ myotubes and $\mathrm{CHO}-\mathrm{AR}$ cells were labeled with ${ }^{125} \mathrm{I}-\alpha \mathrm{BTX}$, solubilized and applied to a $5-20 \%$ sucrose density gradient (Black et al., 1987). The toxinreceptor complexes from both $\mathrm{C} 2$ and $\mathrm{CHO}-\mathrm{AR}$ cells migrated to identical positions in the gradient, corresponding to approximately $9 \mathrm{~S}$ (Fig. 5). By this criterion, the AChR appears to be similar in size and shape to the fully assembled receptor normally found in $\mathrm{C} 2$ cells.

The conclusion that the CHO-AR AChR represents fully assembled receptor is supported further by examination of the association rate constants for ${ }^{125} \mathrm{I}-\alpha \mathrm{BTX}$ binding to $\mathrm{C} 2$ and $\mathrm{CHO}-$ AR cells. When initial rates of association of ${ }^{125} \mathrm{I}-\alpha \mathrm{BTX}$ with the surface receptor were determined, a value for the rate constant of $3.5 \times 10^{4} \mathrm{M}^{-1} \mathrm{sec}^{-1}$ was obtained for CHO-AR cells, and of $2.4 \times 10^{4} \mathrm{M}^{-1} \mathrm{sec}^{-1}$ for $\mathrm{C} 2$ myotubes. The initial rate of toxin binding in both cases was decreased more than $90 \%$ by 1 тм $d$-tubocurarine (data not shown).

\section{Regulation of the surface receptor}

The proportion of total AChR expressed on the surface of CHOAR cells was determined by comparing ${ }^{125} \mathrm{I}-\alpha \mathrm{BTX}$ binding to intact cells with that seen in whole-cell extracts. In both cases, the toxin-receptor complex was immunoprecipitated with $\mathrm{mAb}$ $88 \mathrm{~B}$, so that only assembled AChR, and not unassembled $\alpha$-subunit, would be measured. Internal AChR was also determined by measuring ${ }^{125} \mathrm{I}-\alpha \mathrm{BTX}$ binding to extracts of cells that had previously been incubated with unlabeled toxin to block surface receptors. The values obtained for internal $\mathrm{AChR}$ were the same when measured by either method. The pool of internal receptors in CHO-AR cells was estimated in this way to be approximately
Table 2. Effect of myasthenic serum, sodium butyrate treatment, or incubation at $30^{\circ} \mathrm{C}$ on surface $\mathrm{AChR}$ levels in $\mathrm{CHO}$-AR cells and $\mathrm{C} 2$ myotubes

\begin{tabular}{llcl} 
& \multicolumn{3}{l}{${ }^{125} \mathrm{I}-\alpha \mathrm{BTX}$ binding (fmol/mg protein) } \\
\cline { 2 - 3 } Assay & $\mathrm{C} 2$ & $\mathrm{CHO}-\mathrm{AR}$ \\
\hline Control & $541.3 \pm 3.5(100)$ & $78.3 \pm 1.3(100)$ \\
Myasthenic serum & $324.7 \pm 16.6(60)$ & $44.2 \pm 3.2(56)$ \\
Butyrate & $344.9 \pm 17.7(64)$ & $258.0 \pm 13.1(329)$ \\
$30^{\circ} \mathrm{C}$ & $416.8 \pm 20.4(77)$ & $139.0 \pm 4.6(177)$
\end{tabular}

Cells were pretreated with myasthenic serum $(4 \mathrm{mg} / \mathrm{ml})$ for $2 \mathrm{hr}$ at $37^{\circ} \mathrm{C}$ in medium that was otherwise serum-free or with $6 \mathrm{~mm}$ sodium butyrate overnight at $37^{\circ} \mathrm{C}$ or placed in $\mathrm{a} 30^{\circ} \mathrm{C}$ incubator overnight. Nonimmune human serum had no effect on toxin binding to either $\mathrm{C} 2$ or CHO-AR cells. They were then incubated with ${ }^{125} \mathrm{I}-\alpha \mathrm{BTX}$ for $90 \mathrm{~min}$ at $37^{\circ} \mathrm{C}$ as described in Table 1 . Data are means \pm SEM of 2 independent experiments and are expressed as $\mathrm{fmol} / \mathrm{mg}$ protein. The numbers in brackets are expressed as a percentage of control.

$23 \%$ of the total receptor, a value similar to that seen with $\mathrm{C} 2$ myotubes. We next examined the metabolic half-life of the surface AChR. Because AChRs on the surface of $\mathrm{CHO}$ cells presumably lack interactions with the cytoskeleton or extracellular matrix that are normally found in muscle cells, we were interested to compare the metabolic turnover of surface AChRs expressed in the transfected cells with that of muscle cells. Surface AChRs in CHO-AR cells and $\mathrm{C} 2$ myotubes were labeled with ${ }^{125} \mathrm{I}-\alpha \mathrm{BTX}$ and the amount of toxin-receptor complex remaining associated with the cells was determined as a function of time. The half-life of the complex was about $11 \mathrm{hr}$ in the $\mathrm{C} 2$ myotubes and $13 \mathrm{hr}$ in the CHO-AR cells (Table 3 ).

Fibroblasts transfected with cDNA for all 4 Torpedo subunits express surface $\mathrm{AChR}$ at $28-30^{\circ} \mathrm{C}$, but not at $37^{\circ} \mathrm{C}$. Moreover, surface expression was increased by incubating the cells in sodium butyrate (Claudio et al., 1987). We observed generally similar effects with $\mathrm{CHO}-\mathrm{AR}$ cells. Decreasing the temperature from 37 to $30^{\circ} \mathrm{C}$ resulted in an approximately 2 -fold increase in surface toxin-binding activity, whereas sodium butyrate caused about a 3-fold increase. Surface AChR in C2 cells was decreased by both treatments (Table 2 ).

\section{Physiological properties of the AChR}

Mouse muscle AChRs have been extensively studied by electrophysiological methods (Maricq et al., 1985; Sine and Steinbach, 1986; Brehm and Kullberg, 1987; Henderson et al., 1987; Jackson, 1988). Thus, it is possible to compare in detail the functional properties of AChRs in CHO-AR cells with those in

Table 3. Biochemical characteristics of AChRs in CHO-AR cells and in $\mathrm{C} 2$ myotubes

\begin{tabular}{lll} 
Assay & $\mathrm{C} 2$ myotubes & CHO-AR \\
\hline $\begin{array}{l}\text { \% internal AChR (\% total) } \\
\text { Association rate constant of }\end{array}$ & 33 & 23 \\
$\quad{ }^{125} \mathrm{I}-\alpha \mathrm{BTX}\left(\mathrm{M}^{-1} \mathrm{sec}^{-1}\right)$ & $2.4 \times 10^{4}$ & $3.5 \times 10^{4}$ \\
Half-life (hr) & 11 & 13
\end{tabular}

Percent internal AChR was determined as described in Materials and Methods. Each value represents the mean value obtained from 2 separate experiments. The metabolic half-life was determined as described in Gu et al. (1985). The association rate was calculated from the slope of the function: $k t=1 / R_{0}-T_{0} \ln \left[R_{0} T / T_{0} R\right]$, wherc $R_{0}$ is the initial AChR concentration $(2.67 \mathrm{fmol} /$ well $) ; T_{0}$, the initial toxin concentration; $R$ and $T$, respective parameters after time $t$ (in sec) (Gu et al., 1985). 
A

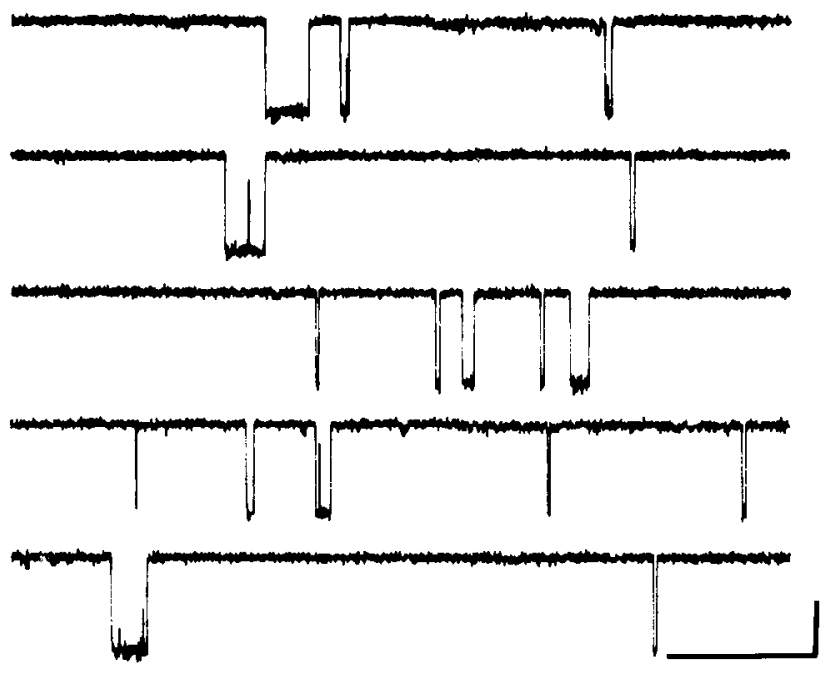

C

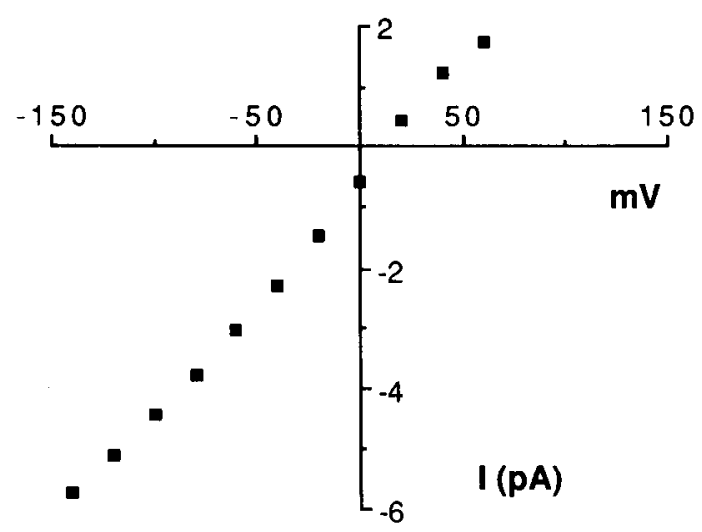

B

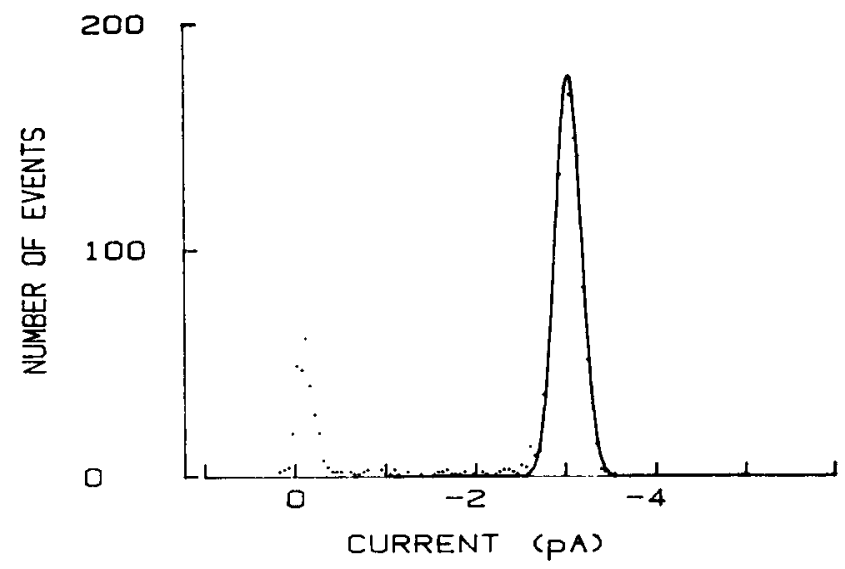

D

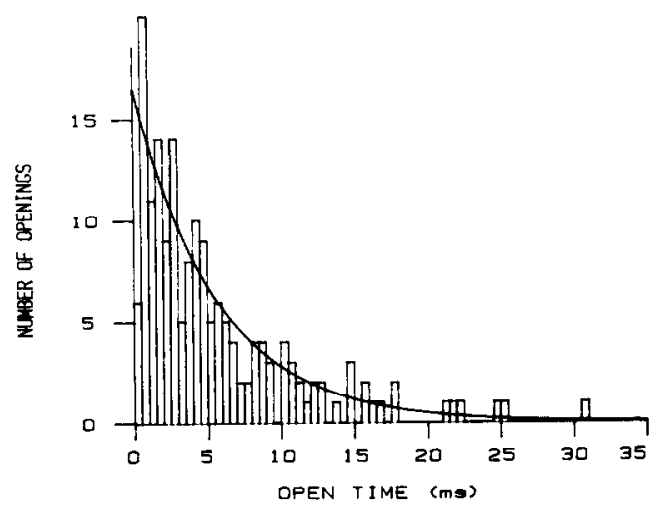

Figure 6. Single-channel recording from CHO-AR 42 cells. Recordings were made as described in Materials and Methods. $A$, Recording obtained from a typical patch in the presence of $200 \mathrm{~nm}$ ACh at a constant holding potential of $-60 \mathrm{mV}$. Horizontal scale bar, $200 \mathrm{msec}$; vertical scale bar, $2 \mathrm{pA}$. All subsequent analyses depicted in this figure are derived from this same recording. $B$, Amplitude histogram showing the distribution of single-channel amplitudes at a constant holding potential of $-60 \mathrm{mV}$; mean amplitude, $-3.02 \mathrm{pA}$. Peak at $0 \mathrm{mV}$ indicates closed-channel noise. $C$, Single-channel current-voltage relationship. The slope conductance for this recording was $40 \mathrm{pS}$ at $0 \mathrm{mV}$; the mean slope conductance from several recordings was $40 \pm 5 \mathrm{pS}(n=6) . D$. Channel open time histogram best fit by a single-exponential distribution yielding a mean open time of $5.6 \mathrm{msec}$ at $-60 \mathrm{mV}$. The continuous curve shows the maximum likelihood fit for a single exponential.

C2 cells. In cell-attached patches with normal saline and 200 nM ACh in the patch electrode, unitary currents through the ACh receptor appeared as discrete steps of inward current at negative membrane potentials. An example is shown in Figure $6 A$. Amplitude histograms of open channel transitions show a single class of events (Fig. $6 \mathrm{~B}$ ) whose single-channel currentvoltage relationship gave a slope conductance of $40 \mathrm{pS}$ (Fig. 6C). For this same recording, the histogram of channel open times is well described by single-exponential distribution of time constant $5.6 \mathrm{msec}$ (Fig. $6 D$ ). In a recording with $5 \mathrm{~mm}$ carbachol in the patch electrode, the time constant was $1.1 \mathrm{msec}$ (data not shown). The single-channel open times and conductances are in excellent agreement with those described for the embryonic form of the ACh receptor channel expressed in developing skeletal muscle of rat and mouse (Siegelbaum et al., 1984; Brehm and Kullberg, 1987; Henderson et al., 1987), in C.2 cells (Maricq et al., 1985), and in Xenopus oocytes (Mishina et al., 1986).

Channel sensitivity to ACh was tested using inverted, outsideout patches, in which the extracellular surface of the patch faces the bathing medium. Prior to the addition of $\mathrm{ACh}$ to the bath, channel activity was not observed (Fig. $7 A$ ), but could be observed within 1 minute of $\mathrm{ACh}$ addition (Fig. $7 B$ ). Subsequent addition of 200 nм $\alpha$ BTX to the bath diminished channel activity to barely detectable levels (Fig. 7C). In similar recordings, ACh-activated channels were silenced after the addition of 10 $100 \mathrm{~mm}$ curare (data not shown). The physiological results taken together strongly suggest that the major class of AChRs expressed on the surface of CHO-AR cells is fully assembled receptor of the embryonic type.

In some cell-attached patches, channels with a smaller conductance were seen. These channels were detected neither in the absence of cholinergic agonists nor in untransfected cells. An example of a patch containing both the $24 \mathrm{pS}$ channel and the more common $45 \mathrm{pS}$ channel is shown in Figure 8 . With 100 mM carbachol in the patch pipet, the mean channel open time of the smaller channel shown in the patch was best described as a single-exponential distribution with a time constant of 1.5 msec compared to $2.0 \mathrm{msec}$ for the larger conductance channel. 
The $24 \mathrm{pS}$ channel displayed bursting behavior at high agonist concentration as did the larger conductance channel. As this channel was present in less than $5 \%$ of the patches observed, its properties were not extensively studied.

\section{Discussion}

The aim of our experiments was to obtain expression of the mammalian muscle AChR in nonmuscle cells and to compare its properties with those of the protein in its native environment. After transfection of CHO cells with a mixture of the 4 cDNAs coding for the subunits of the mouse muscle AChR in a plasmid containing a selectable marker, $25 \%$ of the resulting G418-resistant clones were shown by Southern analysis to contain all 4 cDNAs (data not shown). Approximately $6 \%$ of the clones expressed $\alpha \mathrm{BTX}$ binding activity on the cell surface. Northern analysis of one of these clones (CHO-AR42) revealed the presence of $\mathrm{mRNAs}$ for all 4 subunits at levels that were comparable to those seen in $\mathrm{C} 2$ myotubes.

Several lines of evidence suggest that the toxin-binding activity on the surface of CHO-AR cells represents full assembled AChR containing all 4 subunits. First, mAb $88 \mathrm{~B}$, a monoclonal antibody that recognizes the $\delta$-subunit with high affinity and the $\gamma$-subunit with lower affinity, precipitated both bound toxin and $\alpha$ - and $\beta$-subunits. Thus, $\delta$ - and/or $\gamma$-subunit must be associated with $\alpha$ - and $\beta$-subunits in the transfected cells. The presence of $\gamma$-subunit in the AChR expressed by CHO cells is also indicated by the susceptibility of one of the toxin-binding sites to blockage by a myasthenic serum. The specific site recognized by the antibody acquires its specificity by association of the $\alpha$-with $\gamma$-subunit (Gu et al., 1985; Blount and Merlie, 1989; Gu et al., unpublished observations). Second, the toxin-binding activity on the surface of CHO-AR cells had the same sedimentation constant as the AChR from C2 cells, indicating that the AChR in CHO-AR cells has the same size and shape, as well as the same association kinetics for the toxin-binding reaction, as the native AChR. Finally, the AChR in CHO-AR cells is fully functional, with properties similar to those seen in muscle cells.

Approximately $70 \%$ of the total AChR in CHO-AR cells represented surface receptor, similar to the value found in $\mathrm{C} 2 \mathrm{my}$ otubes. Thus, CHO-AR cells apparently transport the assembled $\mathrm{AChR}$ to the surface with normal efficiency. In contrast to $\mathrm{C} 2$ myotubes, the amount of AChR expressed on the surface of CHO-AR cells was increased by sodium butyrate and by incubating the cells at $30^{\circ} \mathrm{C}$ rather than at $37^{\circ} \mathrm{C}$. Similar effects have been seen in transfected fibroblasts that express the Torpedo AChR (Claudio et al., 1987) and in COS cells expressing all 4 Torpedo subunits (S. Verrall, J. Forsayeth, and Z. W. Hall, unpublished observations). In the absence of these treatments, the AChR is not detected in the transfected fibroblasts but is found in CHO-AR cells at a level that is about $10 \%$ of that found in $\mathrm{C} 2$ myotubes (Table 1). Thus, the properties of the $\mathrm{AChR}$ in these cells can be examined under physiological conditions. It is also worth noting that, in contrast to the original observation of Gorman et al. (1983), it does not appear to be necessary to include butyrate in the transfection procedure in order to obtain an effect subsequently.

Examination of the metabolic turnover time of the AChR in CHO-AR cells was of interest because of the possibility that muscle-specific interactions with the cytoskeleton or extracellular matrix might affect the turnover of the AChR in the membrane. In fact, the rate of degradation of surface AChR in CHOAR cells was almost identical to that seen in $\mathrm{C} 2$ cells, suggesting
A

B

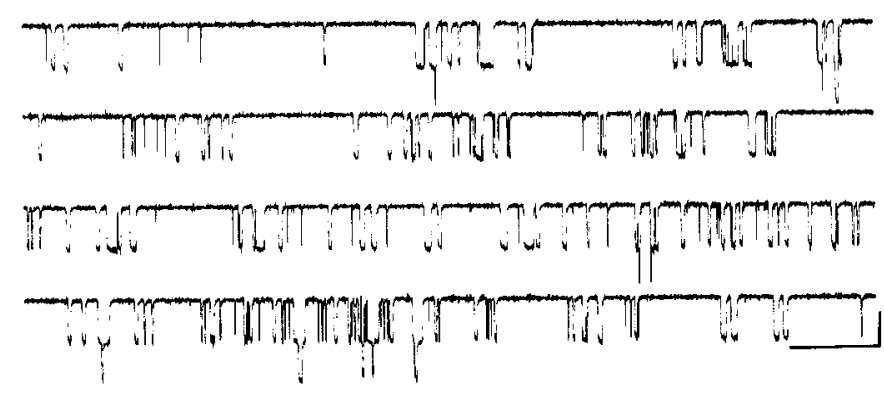

C

Figure 7. Effect of a $\alpha \mathrm{BTX}$ on AChR activity in CHO-AR cells. Recordings were made as described in Materials and Methods. $A$, Recording from an inverted patch in the absence of $\mathrm{ACh}$ at a constant holding potential of $-120 \mathrm{mV}$. $B$, Recording from the same patch $\sim 5$ min after the addition of $1 \mathrm{mM} A C h$ to the bath. $C$, Recording from the same patch $5 \mathrm{~min}$ after addition of $200 \mathrm{nM} \alpha$ BTX to the bath. Horizontal scale bar, $200 \mathrm{msec}$; vertical scale bar, $4 \mathrm{pA}$.

that in neither case were such interactions important in determining the half-life of the reccptor in the membranc. Our results, of course, do not exclude the possibility of an interaction between the AChR and some ubiquitous cellular protein(s). It was also of interest to note that the surface AChR in CHO-AR cells was not aggregated in large clusters such as those seen in $\mathrm{C} 2$ myotubes. It will be of interest to determine if cotransfection with other proteins or the addition of clustering factors such as agrin will stimulate AChR clustering in CHO-AR cells.

The physiological properties of the mouse muscle AChR expressed in CHO-AR cells can be compared to those of the vertebrate muscle $\mathrm{AChR}$ in situ, which have been well described. The channel open times and single-channel conductances are in excellent agreement with those measured in developing skeletal muscle and in C2 myotubes (Siegelbaum et al., 1984; Maricq et al., 1985; Brehm and Kullberg, 1987; Henderson et al., 1987). Channel activity is blocked by $d$-tubocurarine and in the presence of high agonist concentrations shows the burst kinctics characteristic of the desensitized AChR (Sakmann et al., 1983). In about $5 \%$ of patches, a second channel with single-channel conductance of $24 \mathrm{pS}$ was seen. Channels of similar size have recently been reported in developing Xenopus muscle and in Xenopus oocytes injected with mRNA for $\alpha$-, $\beta$-, and $\delta$-subunits (Kullberg et al., 1990). This channel type thus could represent misassembled receptor containing only 3 of the subunits. Experiments in this laboratory with transfected COS cells have shown that toxin binding can be expressed on the surface after transfection with $\alpha-, \beta$-, and $\gamma$-subunit cDNAs (unpublished observations).

In summary, the mouse muscle AChR expressed in transfected CHO cells has the pharmacological, electrophysiological, and metabolic properties of the receptors normally found in $\mathrm{C} 2$ cells. Such transfected cell lines will be valuable tools in the 
A
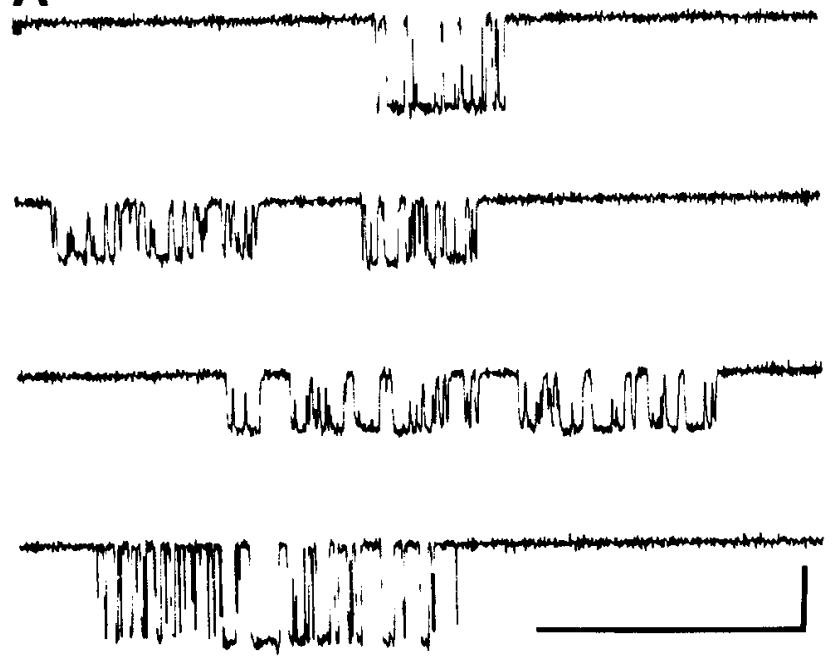

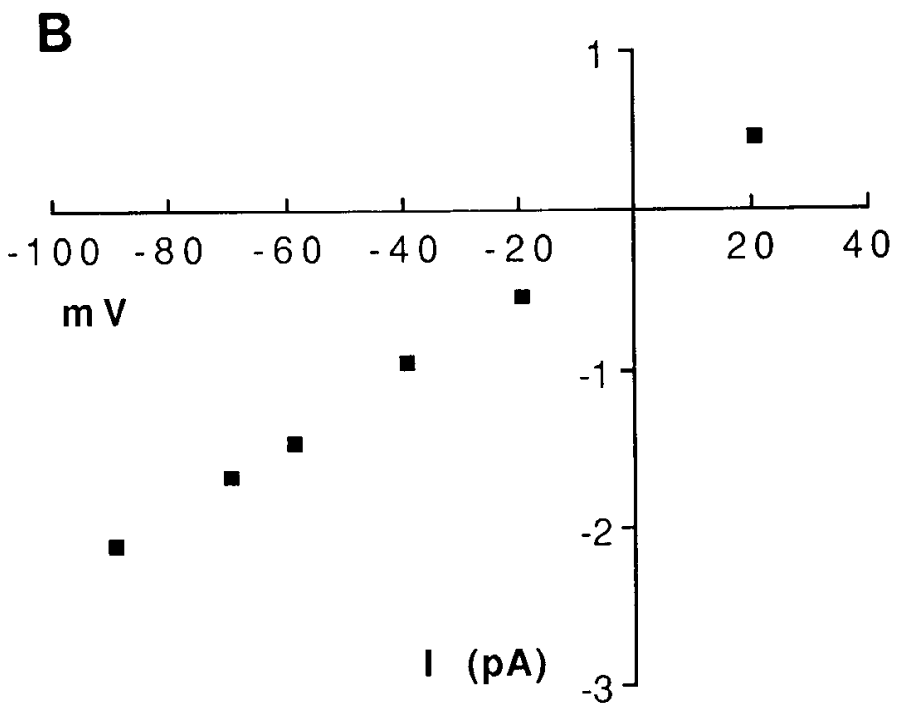

Figure 8. Recording of both the 45 and $24 \mathrm{pS}$ channels in a single patch of CHO 42 cells. Recordings were made as described in Materials and Methods. $A$, Recording of channel activity in the presence of $100 \mu \mathrm{M}$ carbachol at a constant holding potential of $-60 \mathrm{mV}$. Horizontal scale bar, $200 \mathrm{msec}$; vertical scale bar, $2 \mathrm{pA}$. B. Single-channel current-voltage relationship of the $24 \mathrm{pS}$ channel. Single-channel current reversed direction at $2.0 \mathrm{mV}$.

study of the processes of AChR synthesis, assembly, and transport to the surface.

\section{References}

Black RA, Goldman D, Hochswender S, Lindstrom J, Hall ZW (1987) Genetic variants of $\mathrm{C} 2$ muscle cells that are defective in synthesis of the alpha subunit of the acetylcholine receptor. J Cell Biol 105:13291336.

Blount P, Merlie JP (1988) Native folding of an acetylcholine receptor $\alpha$ subunit expressed in the absence of other subunits. J Biol Chem 263:1072-1080.

Blount P, Merlie JP (1989) Molecular basis of the two non-equivalent ligand binding sites of the muscle nicotinic acetylcholine receptor. Neuron 3:349-357.

Bradford MM (1976) A rapid and sensitive method for the quantitation of microgram quantities of protein utilizing the principle of protein-dye binding. Anal Biochem 72:248-254.

Brehm P, Kullberg R (1987) Acetylcholine receptor channels on adult mouse skeletal muscle are functionally identical in synaptic and nonsynaptic membrane. Proc Natl Acad Sci USA 84:2550-2554.

Brockes J, Hall ZW (1975) Acetylcholine receptors in normal and denervated rat diaphragm muscle. II. Comparison of junctional and extra-junctional receptors. Biochemistry 14:2100-2106.

Buonanno A, Mudd J, Shah V, Merlie JP (1986) A universal oligonucleotide probe for acetylcholine receptor genes: selection and sequencing of cDNA clones for the mouse muscle $\beta$ subunit. J Biol Chem 261:16451-16458.

Changeux J-P, Devillers-Thiery A, Chemouilli P (1984) Acetylcholine receptor: an allosteric protein. Science 225:1335-1345.

Claudio T, Green WN, Hautman DS, Hayden D, Paulson HL, Sigworth FJ, Sine SM, Swedlund A (1987) Genetic reconstitution of functional acetylcholine receptor channels in mouse fibroblasts. Science 238:1688-1693.

Claudio T, Paulson HL, Green WN, Ross AF, Hartman DS, Hayden D (1989) Fibroblasts transfected with Torpedo acetylcholine receptor $\beta-, \gamma-$, and $\delta$-subunit cDNAs express functional receptors when infected with a retroviral $\alpha$ recombinant. J Cell Biol 108:2277-2290.

Colquhoun D, Sigworth FJ (1983) Fitting and statistical analysis of single-channel records. In: Single channel recordings (Sakmann B, Neher E, eds). New York: Plenum.

Favaloro J, Treisman R, Kamen R (1980) Transcription maps of polyoma virus-specific RNA: analysis by two dimensional nuclease S1 gel mapping. Methods Enzymol 65:718-725.
Fourney RM, Miyakoshi J, Day RS III, Patterson MC (1988) Northern blotting: efficient RNA staining and transfer. Bethesda Res Lab Focus 10:5-6.

Froehner SC, Douville K, Klink S, Culp WJ (1983) Monoclonal antibodies to cytoplasmic domains of the acetylcholine receptor. J Biol Chem 258:7112-7120.

Gorman CM, Howard BH, Reeves R (1983) Expression of recombinant plasmids in mammalian cells is enhanced by sodium butyrate. Nucleic Acids Res 11:7631-7648.

Gu Y, Hall ZW (1988) Characterization of acetylcholine receptor subunits in developing and in denervated mammalian muscle. J Biol Chem 263:12878-12885.

Gu Y, Silberstein L, Hall ZW (1985) The effects of a myasthenic serum on the acetylcholine receptors of C2 myotubes. J Neurosci 5:19091916.

Gu Y, Black RA, Ring G, Hall ZW (1989) A C2 muscle cell variant defective in transport of the acetylcholine receptor to the cell surface. J Biol Chem 264:11952-11957.

Gullick W, Lindstrom J (1983) Mapping the binding of monoclonal antibodies to the acetylcholine receptor from Torpedo californica. Biochemistry 22:3312-3320.

Gunning P, Leavitt J, Muscat G, Ng SY, Kedes L (1987) A human beta-actin expression vector system direct high-level accumulation of antisense transcripts. Proc Nall Acad Sci USA 84:4831-4835.

Hamill OP, Marty A, Neher E, Sakmann B, Sigworth FJ (1981) Improved patch-clamp techniques for high resolution current recordings from cells and cell-free membrane patches. Pfluegers Arch 391:85100.

Henderson LP, Lechleiter JD, Brehm P (1987) Single channel properties of newly synthesized acetylcholine receptors following denervation of mammalian skeletal muscle. J Gen Physiol 89:999-1014.

Inestrosa NC, Miller JB, Silberstein L, Ziskind-Conhaim L, Hall ZW (1983) Developmental regulation of $16 \mathrm{~S}$ acetylcholinesterase and acetylcholine receptors in a mouse muscle cell line. Exp Cell Res 147: 393-405.

Isenberg KE, Mudd J, Shah V, Merlie JP (1986) Nucleotide sequence of the mouse muscle acetylcholine receptor $\alpha$ subunit. Nucleic Acids Res 14:5111.

Jackson MB (1988) Dependence of acetylcholine receptor channel kinetics on agonist concentration in cultured mouse muscle fibres. $J$ Physiol (Lond) 397:555-583.

Kullberg R, Owens JL, Camacho P, Mandel G, Brehm P (1990) Multiple conductance classes of mouse acetylcholine receptors expressed in Xenopus oocytes (in press).

Lapolla RJ, Mayne KM, Davidson, N (1984) Isolation and charac- 
terization of a cDNA clone for the complete protein coding region of the $\delta$ subunit of the mouse acetylcholine receptor. Proc Natl Acad Sci USA 81:7970-7974.

Maricq AV, Gu Y, Hestrin S, Hall Z (1985) The effects of a myasthenic serum on the acetylcholine receptors of $\mathrm{C} 2$ myotubes. II. Functional inactivation of the receptor. J Neurosci 5:1917-1924.

Merlie JP, Sebbane R (1981) Acetylcholine receptor subunits transit a precursor pool before acquiring $\alpha$-bungarotoxin binding activity. $\mathrm{J}$ Biol Chem 256:3605-3608.

Miller C (1989) Genetic manipulation of ion channels: a new approach to structure and mechanism. Neuron 2:1195-1205.

Mishina M, Kurosaki T, Tobimatsu T, Morimoto Y, Noda M, Yamamoto T, Tereo M, Lindstrom J, Takahashi T, Kuno M, Numa S (1984) Expression of functional acetylcholine receptor from cloned cDNAs. Nature 307:604-608.

Mishina M, Toshiyuki T, Keiji I, Noda M, Takahashi ?, Tomoyuki T, Numa S, Methfessel C, Sakmann B (1986) Molecular distinction between fetal and adult forms of the muscle acetylcholine receptor. Nature 321:406-411.

Ralston E, Hall ZW (1989) Transfer of a protein encoded by a single nucleus to nearby nuclei in multinucleated myotubes. Science 244 : 1066-1069.

Sakmann B, Bormann J, Hamill OP (1983) Ion transport by single receptor channels. Cold Spring Harb Symp Quant Biol 48:247-257.
Salpeter MM (1987) Development and neural control of the neuromuscular junction and of the junctional acetylcholine receptor. In: The vertebrate neuromuscular junction (Salpeter MM, ed), pp 55115. New York: Liss.

Schuetze SM, Role LW (1987) Developmental regulation of nicotinic acetylcholine receptors. Annu Rev Neurosci 10:403-457.

Siegelbaum SA, Trautmann A, Koenig J (1984) Single acetylcholineactivated channel currents in developing muscle cells. Dev Biol 104: 366-379.

Sine SM, Steinbach JH (1986) Activation of acetylcholine receptors on clonal mammalian $\mathrm{BC} 3 \mathrm{H}-1$ cells by low concentrations of agonist. J Physiol (Lond) 373:129-162.

Tzartos SJ, Rand DE, Einarson BL, Lindstrom JM (1981) Mapping of surface structures of Electrophorus acetylcholine receptor using monoclonal antibodies. J Biol Chem 256:8635-8645.

Urlaub G, Chasin LA (1980) Isolation of Chinese hamster cell mutants deficient in dihydrofolate reductase activity. Proc Natl Acad Sci USA 77:4216-4220.

Wigler M, Pellicer A, Silverstein S, Axel R, Urlaub G, Chasin L (1979) DNA-mediated transfer of the adenine phosphoribosyltransferase locus into mammalian cells. Proc Natl Acad Sci USA 76:1373-1376.

Yu L, Lapolla RJ, Davidson N (1986) Mouse muscle nicotinic acetylcholine receptor $\gamma$ subunit: cDNA sequence and gene expression. Nucleic Acids Res 14:3539-3555. 